\title{
DISTRIBUTION OF IMPURITIES IN THE BASES OF HIGH VOLTAGE Si DIODES *
}

\author{
R. Pūras, S. Sakalauskas, J. Vaitkus, and Z. Vaitonis \\ Vilnius University, Saulètekio 9, LT-10222 Vilnius, Lithuania \\ E-mail: romualdas.puras@ff.vu.lt
}

Received 29 September 2005

\begin{abstract}
Spatial distribution of impurities in the base of high voltage planar diodes with additionally incorporated Au atoms ( $p-n$ junction area from 1 to $\left.270 \mathrm{~mm}^{2}\right)$ was inferred according the capacitance-voltage $(C-U)$ characteristics measured by industrial capacitance meters. The capacitance divider and linearly varying voltage method (with the amplitude up to $1000 \mathrm{~V}$ ) were additionally used to extend the operation of capacitance meters to a wider frequency range and to eliminate the influence of reverse current. We had found a nonuniform distribution of dopants (Au atoms) in the diode base, which are introduced to improve the frequency characteristics of the diodes.
\end{abstract}

Keywords: high voltage planar diode, impurity distribution in diode bases, capacitance-voltage characteristics, reverse current

PACS: 85.30.De, 73.40.Lq

\section{Introduction}

High voltage semiconductor diodes of various power are operating in modern electronic equipment, for example in power supply sources. Generally, the diodes are fabricated by planar silicon technology. The power of such diodes is determined by area and thermal regime of $p-n$ junction. The maximal working voltage of the junction is limited by its electric breakdown. The type of breakdown and the value of breakdown voltage depend on impurity density in both $p$ and $n$ regions. This voltage may exceed $1000 \mathrm{~V}$ for silicon $p-n$ junctions, but in the case of a planar diode it is noticeably lower due to a surface breakdown. Therefore equipotential rings are formed in manufacturing process to eliminate the surface breakdown.

High voltage diodes frequently operate in alternating current rectifying circuits at frequencies exceeding $1000 \mathrm{kHz}$, therefore low impurity density in one of the junction region may ensure a high breakdown voltage. However, high voltage drop in this region may occur for the diode operating in a direct current regime. The other disadvantage is related to a long lifetime of charge carriers, which worsens the frequency characteristics of the diode. Incorporation of gold atoms into the junction region with lower impurity density (the

\footnotetext{
* The report presented at the 36th Lithuanian National Physics Conference, 16-18 June 2005, Vilnius, Lithuania.
}

base) $[1,2]$ can noticeably reduce the lifetime of charge carriers resulting in improved frequency characteristics of the diodes. However, nonuniform impurity distribution in the diode base may occur due to additional dopant $(\mathrm{Au})$ incorporation. The aim of this work was to investigate the impurity distribution in the bases of high voltage diodes and to estimate the influence of this distribution on the characteristic voltage of avalanche breakdown. To our knowledge, no studies have been performed on similar high voltage diodes so far.

\section{Samples and investigation methods}

High voltage planar silicon diodes fabricated by the company "Vilniaus Ventos Puslaidininkiai" were investigated. The $p-n$ junction area of the diodes ranged from 1 to $270 \mathrm{~mm}^{2}$. Impurity density in the diode base (in our case it was electronic conduction region of a semiconductor) was low to ensure high working voltage. Low impurity density is known to enhance recombination rate resulting in improved frequency characteristics. This operation was carried out on diodes, although a limited gold penetration depth generated nonuniform impurity distribution.

Distribution of doping impurity in a diode base was determined from the capacitance-voltage $(C-U)$ characteristics measured by different methods. High sensitivity and accuracy may be achieved by using 


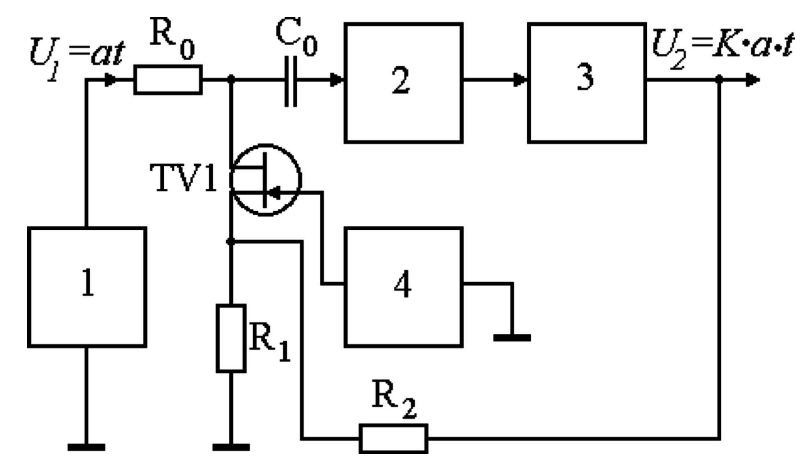

Fig. 1. Schematic diagram of linearly varying voltage source. 1 is linearly varying low voltage source, 2 is power amplifier with stepup voltage transformer, 3 is voltage rectifier with low frequency filter, 4 is high frequency generator, modulating operation of junction transistor $T V 1, R_{1}$ and $R_{2}$ are resistors determining negative feedback depth.

commercial measuring techniques, for example E7-12 or Fluke PM6304. However, both of them have limited application due to low frequency interval and low reverse voltage applied to a testing sample. Capacitance divider method avoiding the limitations mentioned above has been used in low frequency region (up to $0.1 \mathrm{~Hz}$ ). Main limitations of the method are low accuracy (measurement error can reach \pm 5 to $7 \%$ and long duration of the measurement process. But a linearly varying voltage (or triangular pulse) method described in [3] is characterized by high operation rate. Additionally, it is important to notice that linearly varying high voltage source (at least up to $1000 \mathrm{~V}$ ) is necessary for the investigation of high voltage diodes characteristics. A hand made voltage source has been used in this work. The principle of chopper amplifier with negative feedback was employed. Block diagram of the device is shown in Fig. 1. We used power amplifier with a voltage step-up transformer substituting a high voltage (and high power) source. In such a case two $\pm 30 \mathrm{~V}$ voltage sources with power less than $100 \mathrm{~W}$ were sufficient for operation of the device. The linearly varying output voltage demonstrated a certain component of modulation frequency. The amplitude of this signal was small, but it noticeably enlarged measurement error, and we used low frequency fourth range filter in the measurement circuit to eliminate this component.

\section{Experimental results and discussion}

Planar semiconductor $p-n$ junctions with the dimensions of $1 \times 1,3 \times 2,4 \times 4,8 \times 8,10.5 \times 10.5$, and $19.5 \times 14 \mathrm{~mm}^{2}$ were investigated. The capacitancevoltage characteristics corresponding to the junction area of $1 \mathrm{~mm}^{2}$ are shown in Fig. 2. Capacitance of

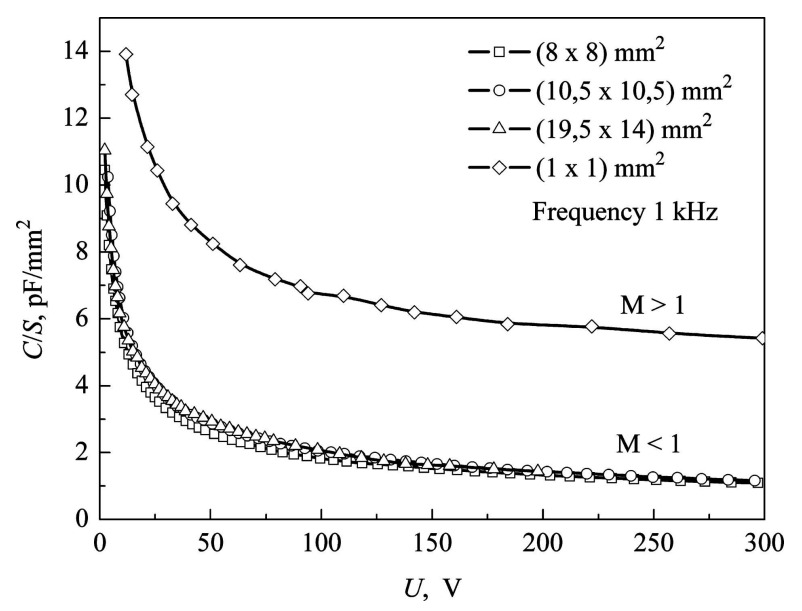

Fig. 2. The dependences of $p-n$ junction capacitance on a reverse voltage.

small area $p-n$ junction was considerably lower compared to its theoretical value [4] due to boundary effects, whereas capacitance of $p-n$ junction with larger area practically corresponded to theoretically estimated values. We used parameter $M=L / S$ ( $L$ is structure perimeter, $S$ is its area) to separate samples into two groups, $M>1$ and $M<1$. For the samples with $M<1$ theoretical and experimental values of capacitance disagreed only slightly (difference less than 10\%) in the frequency range from $10 \mathrm{~Hz}$ to $1 \mathrm{MHz}$, while the corresponding values for the other group disagreed by a factor up to 2 . Consequently, the impurity distribution for the $p-n$ junctions with large area $(M<1)$ was further investigated.

Impurity density distribution in the diode base was determined from the slope angle of the experimental $(S / C)^{2}=f(U)$ relationship [4]:

$$
\frac{\mathrm{d}(S / C)^{2}}{\mathrm{~d} U}=\frac{2}{q \varepsilon \varepsilon_{0} N},
$$

here $q$ is electron charge, $\varepsilon$ is dielectric constant of silicon, $\varepsilon_{0}$ is absolute dielectric constant, $N$ is impurity density in less doped region. Change of slopes of the experimental curves at certain values of the reverse voltage can be seen from Fig. 3. This shows that spatial distribution of impurities in the base region is nonuniform. The reason may be a different $\mathrm{Au}$ atom penetration depth in the base region. Distribution of impurities determined according to the dependence (1) is shown in Fig. 4. This distribution is described in this work by the following relationship:

$$
N_{\mathrm{D}}(x)=\frac{N_{1}+N_{2}}{2}+\frac{N_{2}-N_{1}}{2} \tanh (a+b x),
$$

here $N_{\mathrm{D}}(x)$ is donor impurity density in less doped region, $N_{1}$ and $N_{2}$ are the lowest and the highest donor 


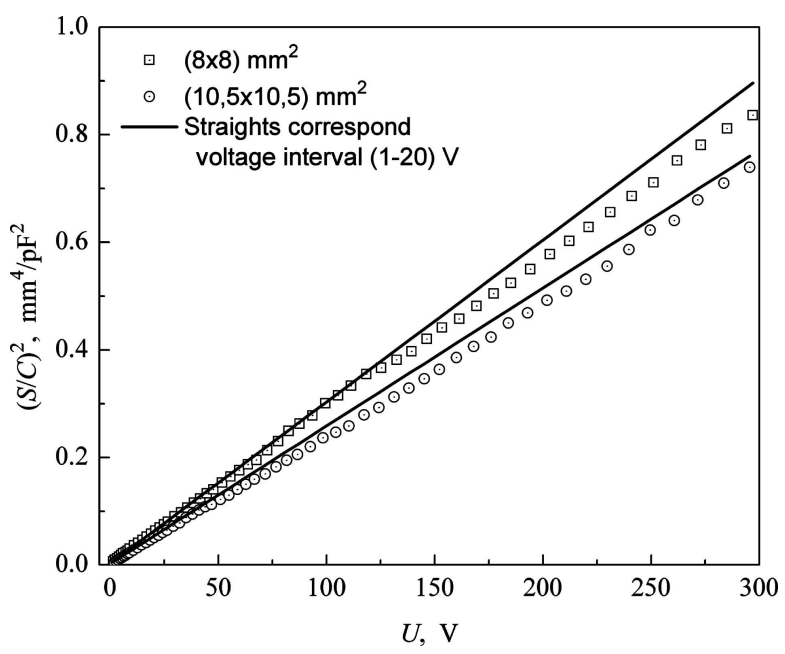

Fig. 3. $(S / C)^{2}$ versus reverse voltage. The measured $(S / C)^{2}$ values of $10.5 \times 10.5 \mathrm{~mm}^{2}$ and $19.5 \times 14 \mathrm{~mm}^{2}$ diode structures were similar within experiment errors.

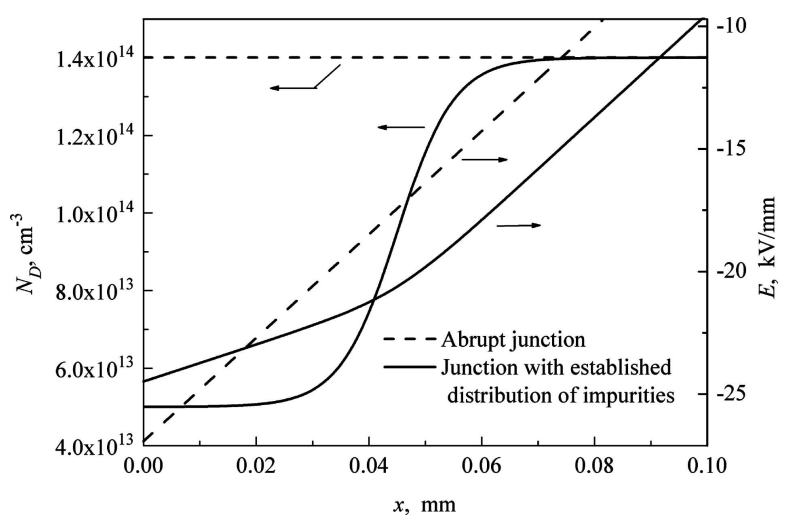

Fig. 4. Spatial distribution of dopant impurities in diode base and electric field strength in a depletion region.

impurity densities respectively, $a$ and $b$ are quantities determined from the experimental results that correspond to impurity density step and position, $x$ is coordinate along the base ( $x=0$ corresponds to the junction boundary). According to experimental results, step of impurity density for different samples varied from $0.5 \cdot 10^{14}$ to $1.4 \cdot 10^{14} \mathrm{~cm}^{-3}$. The depth of Au penetration into the diode bases for majority of samples was estimated to be 40 to $60 \mu \mathrm{m}$ from diode boundary.

It has been established by computer simulation that such impurity distribution in the diode bases creates nonlinear electric field strength variation (Fig. 4). The electric field strength at the diode boundary was lower compared to that in a case of abrupt junction. It means that the breakdown voltage (and working voltage) may be higher.

It is necessary to notice an important peculiarity in measuring the capacitance-voltage characteristic of the diodes. We point out strong dependence of capaci-

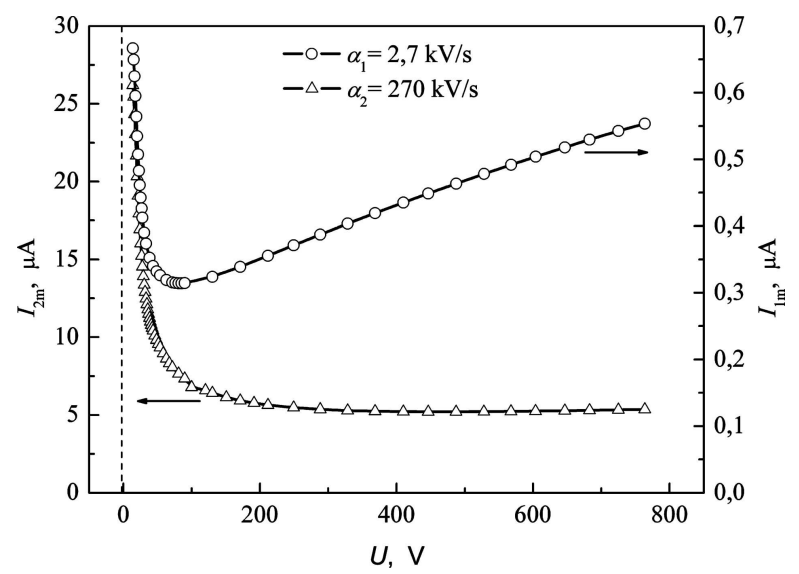

Fig. 5. Dependence of diode reverse current (capacitance component and reverse current component) versus voltage as a function of voltage variation rate $\alpha$.

tance measurement accuracy on reverse current. The reverse current density of silicon $p-n$ junction is approximately proportional to $|U|^{1 / 2}$ while the capacitance is proportional to $|U|^{-1 / 2}$. Therefore special means should be undertaken in low frequency range to avoid large errors when reverse voltage reaches several hundred volts. The current versus voltage as a function of voltage growth rate (frequency) is shown in Fig 5. It can be seen from the figure that the capacitance's current reduces and the reverse current highlights at lower voltage growth rate. For this purpose we used voltage source with linearly varying voltage $(U(t)=a t$, here $a$ is voltage variation rate, $t$ is time), with a rate varying in a wide range. This enables one to change the current of the $p-n$ junction by changing the voltage variation rate. The value of capacitance $C$ as well as the reverse current $I_{\mathrm{a}}$ will depend on the value of moment voltage $U$ at time $t$ [5]:

$$
\left\{\begin{array}{l}
I_{1 m}=\alpha_{1} C_{m}+\frac{U_{m}}{R_{m}}=\alpha_{1} C_{m}+I_{\alpha m}, \\
I_{2 m}=\alpha_{2} C_{m}+\frac{U_{m}}{R_{m}}=\alpha_{2} C_{m}+I_{\alpha m},
\end{array}\right.
$$

here $U_{m}$ is the value of voltage at a certain time $t, C_{m}$ and $R_{m}$ are the corresponding values of capacitance and resistance at voltage $U_{m}, I_{1 m}$ and $I_{2 m}$ are instantaneous values of current corresponding to two different $\alpha$ values. According to the equation (3), it is possible to determine $C_{m}$ and $I_{\alpha m}$ values and the dependences $C-U$ and $I_{\alpha}-U$ for different voltages $U(t)$ and parameters $\alpha$. Moreover, this method is operative not only for investigation of $p-n$ junction capacitance and reverse current, but also enables one to carry out measurements at high voltage. 


\section{Conclusions}

The depth of $\mathrm{Au}$ dopant penetration into a base of high voltage diodes was estimated to be from 40 to $60 \mu \mathrm{m}$. The penetrated $\mathrm{Au}$ atoms are responsible for gradient of impurity distribution in the diode base.

According to computer simulation, the electric field strength is weaker at junction boundary when impurity distribution in the diode base is step-like. This increases the diode working voltage.

The method of linearly varying voltage enables one to examine both the capacitance-voltage characteristics in a wide voltage range and also the dependence of reverse current on applied voltage.

\section{References}

[1] J.R. Hecquefeuille, High voltage low current ultrafast diodes, Express 69, 20-21 (2003).

[2] L.S. Berman and A.A. Lebedev, Capacitance Spectroscopy of Semiconductor Deep Levels (Nauka, Leningrad, 1981) [in Russian].

[3] E. Montrimas, S. Sakalauskas, A. Pažèra, and S. Tamošiūnas, Influence of slow surface levels to electrical properties of MOS structures and method of investigation, Electron Technol. 27(3-4), 49-55 (1994).

[4] S.M. Sze, Physics of Semiconductor Devices, 2nd ed. (Wiley and Sons, New York, 1981).

[5] S. Sakalauskas, Basis for Design of Contactless Microelectronic Converters, Dissertaciya doktora tekhnicheskikh nauk (Habil. Dr. thesis) (Vilnius, 1988) [in Russian].

\title{
PRIEMAIŠU PASISKIRSTYMAS AUKŠTOSIOS ITTAMPOS Si DIODU BAZĖSE
}

\author{
R. Pūras, S. Sakalauskas, J. Vaitkus, Z. Vaitonis \\ Vilniaus universitetas, Vilnius, Lietuva
}

\section{Santrauka}

Pateikti pramoninių aukštosios ịtampos diodụ priemaišų pasiskirstymo ju bazès srityse tyrimai. Tyrimams buvo panaudoti plokščiosios sandaros diodai, kurių $p-n$ sandūrų plotai kito nuo 1 iki $270 \mathrm{~mm}^{2}$. Priemaišu pasiskirstymo dèsningumai diodų bazèse buvo nustatyti iš jų voltfaradinių $(C-U)$ kreivių. $C-U$ kreivès buvo matuotos pramoniniais talpos matuokliais. Siekiant pa- tikslinti ju ypatumus plačioje dažnių juostoje ir pašalinti atgalinių srovių ittaką, buvo panaudoti talpinio daliklio ir tiesiškai kintančios itampos (amplitudès siekè 1000 V) būdai. Pastebètas nevienalytis priemaišų pasiskirstymas diodų bazèse, susijęs su priemaišiniais aukso atomais, kurie buvo įterpti i diodų bazes, siekiant pagerinti minètų diodų dažnines charakteristikas. 